\title{
Le $\mathbb{C}^{\mathrm{a}}$ 型物質分解酵素に関する研究 \\ I. Le $e^{a}$ 分解酵素の血清学的作用
}

\author{
古川研・藤沢敬一・垡木治
}

群馬大学医学部法医学教室 (主任 井関尚栄教授)

Grubb and Morgan ${ }^{1)}$ はA，B抢よびH物質 を分解するClostridium welchii (Type B)の培 養液から得られた酵素が， $\mathrm{Le}^{\mathrm{a}}$ 打よび $\mathrm{Le}^{\mathrm{b}}$ 物 質をも分解することを報告した。 Watkins ${ }^{2)}$ は Trichomomas fostus の抽出液は水溶性のA, B, $\mathrm{H}, \mathrm{Le}^{\mathrm{a}}$ おょび $\mathrm{Le}^{\mathrm{b}}$ 物質の血清学的活性を破 壊するが, 志賀赤痢菌や肺炎双球菌 XIV型の 特異多糖体の血清学的性質を破壤しないことを 明らかにし，この抽出液の硫安による精製物は 人のH物質のみを分解し， A, BおよびLewis型 物質を分解しないことを報告している。ついで Watkins ${ }^{3)}$ は $T$. foetus の抽出液は $\mathrm{Le}^{\mathrm{a}}$ 物質 に作用して抗 $\mathrm{Le}^{\mathrm{a}}$ ヒト血清に対する凝集阻上 力や抗 $\mathrm{Le}^{\mathrm{a}}$ ウサギ血清に対する沈降反応を消 失させることを示し, $\mathrm{Le}^{\mathrm{a}}$ 物質の作用は $55^{\circ} \mathrm{C}$ 30分間加熱すると殆んど不活性化されるが, $\mathrm{A} ， \mathrm{~B}$ およびH物質に対する酵素活幽は、上記の 熱処理では安定であることや, 酵素の保存中に $\mathrm{Le}^{\mathrm{a}}$ 分解酵素の活性が消失することから, Le 分解酵素之H分解䣼素之は異るものであろうと 述へている。またこの抽出液は $\mathrm{A} ， \mathrm{~B} ， \mathrm{H}$ およ び $\mathrm{Le}^{\mathrm{a}}$ などの型物質に作用して $20 \%$ の還元糖 々, fucose, galactose および $N$-acetylhexosamine を遊離させることを認めている，Pusztai and Morgan ${ }^{4}$ は $\mathrm{A}_{1} \mathrm{Le}(\mathrm{a}+)$ 型のヒトの 卵巣囊腫から得られた sialomucopolysaccharide にLe 特異性と influenza virusによる 血球凝集反応に対する阻止作用とを認め, さら に5)この sialomucopolysaccharide にT. foetus のLe $\mathrm{L}^{\mathrm{a}}$ 分解酵素を作用させて $\mathrm{Le}^{\mathrm{a}}$ 特琵性 を破壞した場合にはvirusによる血球凝集反応 に対する阻止作用は殆んど破壊されず，Vibrio cholera:の virus-receptor 分解酵素を作用させ た場合には Le $\mathrm{e}^{\mathrm{a}}$ 作用は破壊されずに残ってお り, その際 sialic acid が遊離し, 抗肺炎双球 菌XIV型ウマ血清との交叉反応が増してくる ことを報告している。

Pusztai and Morgan ${ }^{6)}$ 法疍白分解酵素であ る ficinまたは papainを A, B, 此よび $\mathrm{Le}^{\mathrm{a}}$ 物質に作用させると，型作用はかなりこ わされるが透析外液中に単糖や少糖類は見出さ れないことを報告し，さらに”，これらの酵素 を型物質に作用させると，粘度が低下し， peptide を遊離してくるのを久ている.Pusztai and Morgan ${ }^{5)}$, Morgan and Pusztai ${ }^{8)}$ はficin と papain の作用により, 型物質は2 2 種類 の巨大分子部分と diffusible peptide とに分 解され, 巨大分子の活性度はもとの型物質のそ れの数\%を示すが，巨大分子のうちでも小さい 方の部分の活性は大きい方の部分の活性より低 く, また酵素作用の前後でアミノ酸の構成沬変 化するが，楉構成は変らないことを報告してい る.

Watkins and Morgan ${ }^{9)}$ は . foetus $の \mathrm{Le}^{\mathrm{a}}$ 分解酵素の作用が L-fucose で阻止されること を明らかにし，さらに，Kuhn らによって人乳 より分離された L-fucose 含有の少糖類につい て抗 $\mathrm{Le}^{\imath}$ 抢よび抗 $\mathrm{Le}^{\mathrm{b}}$ 抗体に対する反応阻止 作用をしらべた結果，抗 $\mathrm{Le}^{\mathrm{a}}$ 凝集素は lacto$N$-fucopentaose II ${ }^{10)}$ 之 lacto- $N$-fucopentait II とで强く, lacto- $N$-difucohexaose ${ }^{10)}$ でやや引弱 く反応を阻止され，抗Le ${ }^{\mathrm{b}}$ 凝集素は lacto- $N$ difucohexaose ${ }^{10)} と$ lacto- $N$-difucotetraose ${ }^{11)}$ とで弱く反応を阻止されることを認め，lacto- 
$N$-fucopentaose II に $T$ 。 foe'us の酵素を作用 させると抗 $\mathrm{Le}^{\mathrm{a}}$ 抗体に対する沈降反応や凝集 反応への阻止力が消失することを明らかにし た。としてこれらの結果から $\mathrm{Le}^{\mathrm{a}}$ 作用の決定 群としては $\alpha$-L-fucosyl 基が $1 \rightarrow 4$ 結合で, $\beta$-D-galactosyl 基が $1 \rightarrow 3$ 結合で $\beta$-D- $N$ acetylglucosamine に結合したbranched trisaccharide が重要であると述べている，Kuhn und Gauhe ${ }^{11}$ も lacto-difucotetraose が Morganによって抗 L $\mathrm{e}^{\mathrm{b}}$ 凝集素に対する阻止 力があることが明らかにされたことを附記して いる、その後, Kuhn und Gauhe ${ }^{12)}$ はさきの報 告 ${ }^{10)} の$ lacto- $N$-difucohexaose には2種のhexasaccharide が含まれていることを明らかに し、これらを lacto- $N$-difucohexaose I およ
び lacto- $N$-difucohexaose II と名付けた。ま た Morganによってしらべられた結果, lacto $N$-dif ucohexaose II にはLe ${ }^{a}$ 作用が, lacto- $N$ difucohexaose Iには弱い Le $\mathrm{Le}^{\mathrm{b}}$ 作用が認められ たことを報告している。その後, Watkins and Morgan $^{13)}$ は抗 Le $\mathrm{Le}^{\mathrm{v}}$ ヒト血清が lacto-Nfucopentaose II で最も強く，ついで lacto- $N$ difucohexaose II でやや弱く, lacto- $N$-difucohexaose I でも僅かに阻止され，抗 $\mathrm{Le}^{\mathrm{b}}$ ヒト 血清が lacto- $N$-dif ucohexaose I で強く, lacto-dif ucotetraose でやや弱く阻止されるこ とを報告している.Kuhn らが人乳から分離し た主として fucose を含んだ少糖類の構造式を Watkins and Morgan9) の報告によっって示す と次のようである。

1) Lacto- $N$-tetraose (Kuhn und Baer $^{14)}$ )

$O-\beta-\mathrm{D}$-galactosyl-( $1 \rightarrow 3$ )-O- $\beta-\mathrm{D}-N$-acetylglucosaminoyl-( $1 \rightarrow 3)-O-\beta-\mathrm{D}$-galactosyl-

2 ) Lacto- $N$-fucopentaose I (Kuhn, Baer und Gauhe ${ }^{15)}$ )

$(1 \rightarrow 4)$-D-glucose

$O \beta-\mathrm{D}$-galactosyl-( $1 \rightarrow 3)-O-\beta-\mathrm{D}-N$-acetylglucosaminoyl- $(1 \rightarrow 3)-O-\beta-\mathrm{D}$-galactosyl-

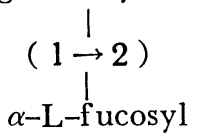

$(1 \rightarrow 4$ )-D-glucose

3 ) Lacto- $N$-f ucopentaose II (Kuhn, Baer und Gauhe ${ }^{10)}$ )

$O-\beta$-D-galactosyl-(1 $\rightarrow 3)-O-\beta-\mathrm{D}-N$-acetylg lucosaminoyl-( $1 \rightarrow 3)-O-\beta-\mathrm{D}$-galactosyl-

$$
(1 \stackrel{\mid}{\rightarrow} 4)
$$

4 ) Lacto- $N$-difucohexaose (Kuhn, Baer und Gauhe ${ }^{10)}$ )

$O-\beta-\mathrm{D}$-galactosyl-( $1 \rightarrow 3)-O-\beta-\mathrm{D}-N$-acetylglucosaminoyl- $(1 \rightarrow 3)-O-\beta-\mathrm{D}$-galactosyl-

$$
(1 \stackrel{\mid}{\rightarrow} 2)
$$

5 ) Fucos'ido-lactose (Kuhn, Baer und Gauhe ${ }^{17)}$ )

$O-\beta$-D-galactosyl- $(1 \rightarrow 4)$-D-glucose

$$
\begin{gathered}
(1 \stackrel{\mid}{\rightarrow} 2) \\
\alpha \text {-L-fucosyl }
\end{gathered}
$$

6 ) Fucosido-galactose

$O-\beta-\mathrm{L}-$ f ucosyl- $(\mathrm{l} \rightarrow 2)-\mathrm{D}$-galactose

7 ) Lacto-dif ucotetraose (Kuhn und Gauhe ${ }^{11)}$ )

$O-\beta-\mathrm{D}$-galactosyl- $(1 \rightarrow 4)-\mathrm{D}$-glucose

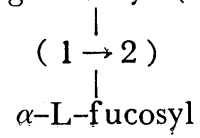

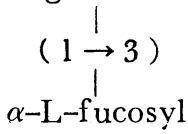


ういで，4の Lacto- $N$-difucohexaose が2種類にわかれ, もとの 4 の構造式のものをI とし, 他 に次のような Lacto- $N$-difucohexaose II があることがわかった。

8 ) Lacto- $N$-difucohexaose II (Kuhn und Gauhe ${ }^{12)}$ )

$O-\beta$-D-galactosyl-( $1 \rightarrow 3)-O-\beta-\mathrm{D}-N$-acetylglucosaminoyl-( $1 \rightarrow 3)-O-\beta-\mathrm{D}$ galactosyl-

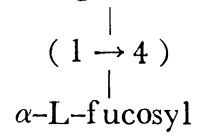

$(1 \rightarrow 4)-D-$ glucose

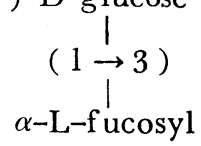

このうちで抗 $\mathrm{Le}^{\mathrm{a}}$ 血清の反応を阻止する少 糖類は $3,8,4$, で, この順に阻止力は弱く なり，抗 $\mathrm{Le}^{\mathrm{b}}$ 血清の反応を阻止する少糖 類は 4, 7 でこの順に阻止力は弱、

Watkins ${ }^{18)}$ は $T$. fortus の酵素を zone el一 ectrophoresis で分画して, A, B, Le $\mathrm{e}^{\mathrm{a}}$ 分解 酵素を含むPreparation I, H分解酵素を含む Preparation II およびB， Le $\mathrm{a}^{\mathrm{a}}$ 分解酵素を含む Preparation IIIに分け，あるH物質に Preparation II を作用させ，H作用を破壊すると抗Le 血清に対する凝集阻止力や沈降反応が増してく ることを認め，H物質に Preparation I を作用 させてH物質中の $\mathrm{Le}^{\mathrm{a}}$ 活性を破壊すると抗肺 炎双球菌XIV型ウマ血清に対する反応が僅か に増し、これにPreparation II を作用させてH 活性を破壊すると， $\mathrm{Le}^{\mathrm{a}}$ 作用が増強し，抗肺 炎双球菌XIV型ウマ血清に対する反応も相当 増強することを認めている。ついで, Preparation Iを作用させて新たに出現した $\mathrm{Le}^{\mathrm{a}}$ 作用 を分解しても抗肺炎双球菌XIV型兵血清に 対する反応に変化がないことを明らかにした。

また，このH分解酵素処理 H物質やLe $\mathrm{Le}^{\mathrm{a}}$ 物質 と抗Le ${ }^{a}$ ウサギ血清との沈降反応は lacto- $N$ fucopentaose II $と$ lacto- $N$-difucohexaose II で阻止されるが, lacto- $N$-fucopentaose II に Preparation I を作用させると抗 $\mathrm{Le}^{\mathrm{a}}$ 抗体に対 する阻止力が消失し, その際 lacto- $N$-fucopentaose II は主として lacto- $N$-tetraose $(O-\beta$ D-galactosyl- $(1 \rightarrow 3)-O-\beta-\mathrm{D}-N$-acetylglucosaminoyl- $(1 \rightarrow 3)-O-\beta-\mathrm{D}$-galactosyl- $(1 \rightarrow 4)-$ D-glucose）とfucose とに分解することを報 告している。

一方 Sneath and $\operatorname{Sneath}^{19}$ \& Le $(\mathrm{a}+\mathrm{b}-)$ 型
血球に $\operatorname{Le}(\mathrm{a}-\mathrm{b}+)$ 型のヒトの血漿を作用させ ると, $\operatorname{Le}(\mathrm{a}+\mathrm{b}+)$ 型に転換し, $\operatorname{Le}(\mathrm{a}-\mathrm{b}+)$ 型 血球に $\operatorname{Le}(\mathrm{a}+\mathrm{b}-)$ 型のヒト血漿を作用させる と $\operatorname{Le}(\mathrm{a}+\mathrm{b}+)$ 型に, Le $(\mathrm{a}-\mathrm{b}-)$ 型のヒトの 血漿を作用させると $\mathrm{Le}(\mathrm{a}-\mathrm{b}$ 一) 型に転換し， また Le $(a-b-)$ 型の血球に $\operatorname{Le}(\mathrm{a}+\mathrm{b}$-)型ま たは Le $(a-b+)$ 型のヒトの血漿を作用させる と Le $(\mathrm{a}+\mathrm{b}-)$ 型または $\operatorname{Le}(\mathrm{a}-\mathrm{b}+)$ 型に転換 することを報告している。

古川, 藤沢, 茂木 ${ }^{20)}$ は $C l$. tertium の 1 株 からの酵素は, $\mathrm{O}(\mathrm{H})$ 物質を分解して $\mathrm{O}(\mathrm{H})$ 作用を消失させるとともに型物質と肺炎双球菌 XIV型との共通抗原物質をも分解するほか, $\mathrm{Le}^{\mathrm{a}}$ 物質やA型物質をも分解することを報告し た。

ここでは Lewis 式血液型の型物質のうち， $\mathrm{Le}^{\mathrm{a}}$ 物質を特異的に分解する酵素を産生する 菌を見出したので，その菌の性状々酵素の型物 質に対する血清学的作用について報告する。

\section{実験材料および方法}

1) 酵素液 : 普通寒天平板上で $37^{\circ} \mathrm{C} ， 24$ 時間培養 した菌体を中性燐酸緩衡液中にとり, 冷却しながらホ モジエナイザーでホモジエナイズし，得られたホモジ エネートに少量のトルエンを加えて時々振蕰しながら $37^{\circ} \mathrm{G}$ に2 4 時間おいて菌体を自家融解させる。この融 解液を Sharples 遠心器で冷却しながら遠心して菌体 残渣を除去し，上清に硫安を加えて30一60\%飽和で沈 澱する部分を遠沈して集め, 少量の蒸溜水に溶解し, 冷水中で48時間透析する・透析内液に 1.5 倍量の冷ア セトンを加え, 生じた沈澱物を遠心し, 沈渣を少量の 蒸溜水に溶解して凍結乾燥した・醭素液にはこの乾燥 粉末をpH7.0の燐酸緩衝液に1\%の割にとかしたもの 
を使用した・また酩菜の分離䞍製には前述の漧燥粉末 $100 \mathrm{mg}$ を $\mathrm{pH} 6.800 .002 \mathrm{M}$ 燐酸緩衝液10 $\mathrm{ml}$ に溶解し, これを Chromatographic tube $(10 \times 450 \mathrm{~mm})$ にDE AE cellulose $2 \mathrm{~g}$ をつめた DEAE cellulose column $(10 \times 100 \mathrm{~mm})$ に吸着させ， pH6.8 では 0.002M， 0.01M，0,05M，0.1M 抢よび 0.15M，pH7.4では $0.01 \mathrm{M}, 0.05 \mathrm{M}, 0.1 \mathrm{M}$ および $0.15 \mathrm{M}, \mathrm{pH} 8.0$ では $0.1 \mathrm{M} お よ ひ ゙ 0.2 \mathrm{M}$ 濃度の荈酸緩衝液で段階的に溶出 を行った・ついで溶出液に硫安を加えて70\%飽和で生 しる沈澱物を集めて透析し，内液について醭素作用の 有無を検査した。溶出速度は $3 \mathrm{ml} / \mathrm{hr}$, 溶出液量は各 100 meである。

2）血液型物質：ヒ卜胃内買よりペプシン消化法と フエノール法で精製したものを使用した。

3）抗血清 : 抗 $\mathrm{O}(\mathrm{H})$ 凝集素にはウナギII 型们清 を，抗 $\mathrm{A}$ と抗 $\mathrm{B}$ 凝集素にはB型とA型のヒト向清を使用 乙，抗 $O(H)$ 沈降素には抗O型向球卜り!血清を，抗 $\mathrm{A}$ と抗B沈降菜には抗A型ヒト肌球ウサギ血清と抗 B 型 ヒト血球ウサギ向清とを使用した。また，抗 $\mathrm{Le}^{\mathrm{a}}$ 凝 集素および沈降素としては抗Os Le $(\mathrm{a}+\mathrm{b}$ 一) 型ヒト睡 液ウサギ伅清を使用し，抗Leb 凝集素には抗OS Le $(\mathrm{a}-\mathrm{b}+)$ 型七ト棰液ウサギ伹清を, 抗 Leb 沈降素 には前記の免疫而清を OS Le $(a-b-)$ 型とOs Le $(\mathrm{a}+\mathrm{b}$ 一 $)$ 型の雨者の胃内層型物質で吸収したものを 使用した。

抗肺炎双球菌XIV型（Pn.XIV）免度伅清としては 抗Pn.XIVトリ癿清を使用した。

4）酵害の作用方法：水溶性の型物質に酵素を作 用させる場合には，型物芘に等量の醭素液を加え， $37^{\circ} \mathrm{C}$ に48時間おき, 水浴中で $100^{\circ} \mathrm{C} 10$ 分間加熱して 酩素作用を破䇈後，遠心して上清をとり，型物留分解 の有無を凝集阻止試験と型特異性沈降反応により判定

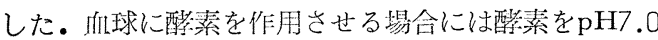
の燐酸緩衡淮と生理的食塩水とを 4 ：1の割合に混じ た buffered saline に溶解し, 洗㧛ff球にこの酥素淮 を等量加え，150 Gで24㭙閒作朋させたのち，3回洗 沙して酵素液を除き，この䣼素処理几球について凝集 素吸収試験を行った。 Le $(a+b-)$ 型とLe $(a-b+)$ 型血球に刘する䤃素作用をしらべる際には，抗 Le ${ }^{\mathrm{a}}$

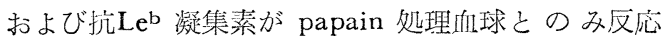
するため, papain 処理向球に酳素を作用させた。

\section{実 験 成 纓}

\section{1. 菌の性状と菌名}

本菌は好気性の細長い桿菌で，時に2 万至数 個の連鎖をなし，芽胞は先端又は中央部に生じ 卵形である.グラム陽性で運動性があり，普通 舆天平板上の集落は円形で死白色，不透明であ り，表面はやや粗造である。生物学的性状はカ タラーゼ陽性, 硝酸塩を還元するがインドール を産生しない.Voges-Proskauer 反応および メチール赤試験は陰性であり，ゼラチンおよび 凝固血清を液化し，牛乳を凝固させる.glucose galactose, mannose, maltose, lactose, sucrose, fructose, mannitol を分解するが，力 スの発生はなく, rhamnose, xylose, arabinose, raffinose, inositol, inulin を分解しな い. 以上の性状は Bergey's Manual of Determinative Bacteriology.に記載されている Bacillus cereus の性状に類似している。

\section{2. 水溶生型物質および血球に対する酵素の 作用}

本菌の出す酥素を $\mathrm{O}(\mathrm{H}), \mathrm{Le}^{\mathrm{a}}$ ，Aおよび B型物質に作用させてみた結果は表1 と表2に示 す如くである。すなわち Le ${ }^{\mathrm{a}}$ 物質にこの菌の出 す酵素を作用させると，抗Le ${ }^{2}$ ウサギ血清に対 する凝集阻止力之沈降反応は消失するが，抗 Pn.XIV型トリ血清に対する凝集阻止力と沈降 反応はかえっていくぶん增強する。また，この 菌の出す酵素は $\mathrm{A}$ 型物質に作用して抗 $\mathrm{A}$ ヒト血

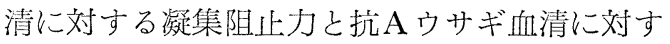
る沈降反応を消失ないし減弱させる。しかし, $\mathrm{O}$ (H) 物質ではそのうちに含まれるLe $\mathrm{Le}^{\mathrm{a}}$ 活性を 消失させるが，抗 $\mathrm{O}(\mathrm{H})$ ウナギ血清に対する 凝集阻止力や，抗 $\mathrm{O}(\mathrm{H})$ トリ血清に刘する沈 降反応，抗Le ${ }^{b}$ ウサギ血清に対する凝集阻止力 および沈降反応などはこの酵素作用によっってな くならない。

またB型物質にこの酵素を作用させても，抗 $\mathrm{B}$ ヒト血清に刘する凝集阻止力や抗 Bウサギ血清 に対する沈降反応は消失しない。すなわちこ の菌は $\mathrm{Le}^{\mathrm{a}}$ 物質やA型物質を分解して $\mathrm{Le}^{\mathrm{a}}$ 活 性やA活性を消失させる酵素を産生しているこ とがわかる。 
表 1 型物質に対寸る酵素作用（凝集阻止試験）

\begin{tabular}{|c|c|c|c|c|c|c|c|c|}
\hline 型物 質 & 抗 血 清 & $\begin{array}{l}\text { 酰:素 } \\
\text { 作用 }\end{array}$ & \multicolumn{3}{|c|}{ 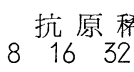 } & \multicolumn{3}{|c|}{$\begin{array}{l}\text { 釈 倍 数 } \\
64128256\end{array}$} \\
\hline \multirow{5}{*}{$\begin{array}{c}\mathrm{O}(\mathrm{H}) \text { 物質 } \\
(0.01 \%)\end{array}$} & $\begin{array}{l}\text { 抗O(H) } \\
\text { ウナギ向清 }\end{array}$ & $\begin{array}{l}\text { 前 } \\
\text { 後 }\end{array}$ & - & - & - & - & $\begin{array}{l}+ \\
+\end{array}$ & $\begin{array}{l}+ \\
+\end{array}$ \\
\hline & 抗Le $e^{i}$ & 前 & - & - & + & + & + & + \\
\hline & ギ䘏清 & 後 & + & + & + & + & + & + \\
\hline & 抗 $\mathrm{Le}$ & 前 & - & - & - & - & + & + \\
\hline & 血清 & 後 & - & - & - & - & + & + \\
\hline \multirow{4}{*}{$\begin{array}{c}\mathrm{Le}^{\mathrm{z}} \text { 物 質 } \\
(0.01 \%)\end{array}$} & 抗Le & 前 & - & - & - & - & + & + \\
\hline & ウサ & 後 & + & + & + & + & + & + \\
\hline & 抗Pn. XIV & 前 & - & - & - & - & + & + \\
\hline & トリ 血清 & 後 & - & - & - & - & - & + \\
\hline \multirow{2}{*}{$\begin{array}{c}\mathrm{A} \text { 型物䁈 } \\
(0.01 \%)\end{array}$} & 抗A & 前 & - & - & - & - & 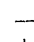 & + \\
\hline & 化ト 秃 清 & 後 & - & - & + & + & + & + \\
\hline \multirow{2}{*}{$\begin{array}{c}\mathrm{B} \text { 型物 質 } \\
(0.01 \%)\end{array}$} & 抗B & 前 & - & - & - & - & 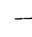 & \\
\hline & 七ト Ifil 清 & 後 & & - & - & & & + \\
\hline
\end{tabular}

表 2 型物質に対する酵素作用（沈降反応）

型物質抗血清酲素 抗原稀釈倍数

\begin{tabular}{|c|c|c|c|}
\hline $\begin{array}{c}\mathrm{O}(\mathrm{H}) \text { 物質 } \\
(0.01 \%)\end{array}$ & 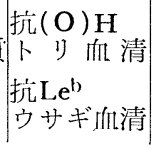 & $\begin{array}{l}\text { 前 } \\
\text { 後 } \\
\text { 前 } \\
\text { 後 }\end{array}$ & $\begin{array}{l}\text { H\#H+ } \\
H+H+ \\
H+H+-- \\
H+H+--\end{array}$ \\
\hline $\begin{array}{c}\mathrm{Le}^{\mathrm{a}} \text { 物 質 } \\
(0.01 \%)\end{array}$ & \begin{tabular}{|l} 
抗Le \\
ウサザ血清 \\
抗Pn.XIV \\
$ト$ トリ向清
\end{tabular} & $\begin{array}{l}\text { 前 } \\
\text { 後 } \\
\text { 前 } \\
\text { 後 }\end{array}$ & $\begin{array}{l}H+ \pm+-- \\
-1+- \\
H+H++- \\
H+H++\end{array}$ \\
\hline $\begin{array}{c}\mathrm{A} \text { 型物質 } \\
(0.01 \%)\end{array}$ & $\begin{array}{l}\text { 抗A } \\
\text { ウサギ向清 }\end{array}$ & $\begin{array}{l}\text { 前 } \\
\text { 後 }\end{array}$ & $\begin{array}{l}H \#++t \\
\#+t+ \pm\end{array}$ \\
\hline $\begin{array}{c}\mathrm{B} \text { 型物 質 } \\
(0.01 \%)\end{array}$ & 抗B & $\begin{array}{l}\text { 前 } \\
\text { 後 }\end{array}$ & $\begin{array}{l}H \#+++ \\
\#+t+t+\end{array}$ \\
\hline
\end{tabular}

つぎに，血球の血液型物質にこの酵素を作用 させてみた結果は表3に示すようである。 OLe $(\mathrm{a}+\mathrm{b}-)$ 型血球にこの酵素を作用させると，抗 $\mathrm{Le}^{\mathrm{a}}$ ウサギ血清中の凝集素に対する吸収力は全 く消失するが，抗Pn.XIV型トリ血清中の七 卜血球に対する凝集素を吸収する力はかえって いくぶん増強し, 抗 $\mathrm{O}(\mathrm{H})$ ウナギ血清中の凝 集素に対する吸収力には酵素作用の前後で差を みない、また， $\mathrm{A}$ 型血球にこの酵素を作用させ ると，抗A凝集素に対する吸収力は減弱する。 しかし, OLe $(a-b+)$ 型血球抢よびB型血球 にこの菌の出す酵素を作用させても, OLe（a $-b+)$ 型血球の抗 $\mathrm{O}(\mathrm{H})$ ウナギ血清と抗L $\mathrm{e}^{\mathrm{b}}$
表了向球に対する醭素作用（凝集素吸収試験）

\begin{tabular}{|c|c|c|c|c|c|c|c|c|}
\hline 球 & 抗 血 清 & 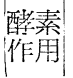 & & fil 1 & $\begin{array}{l}\text { 稀 } \\
8\end{array}$ & $\begin{array}{l}\text { 棌 } \\
16\end{array}$ & 倍 & 64 \\
\hline \multirow{2}{*}{$\begin{array}{l}\text { OLe } \\
(a-b+)\end{array}$} & $\begin{array}{l}\text { 抗O }(\mathrm{H}) \\
\text { ヴギ }\end{array}$ & $\begin{array}{l}\text { 前 } \\
\text { 後 }\end{array}$ & - & - & - & - & - & $\begin{array}{l}+ \\
+\end{array}$ \\
\hline & $\begin{array}{l}\text { 抗Le } \\
\text { ウザ゙ffll清 }\end{array}$ & $\begin{array}{l}\text { 前 } \\
\text { 後 }\end{array}$ & $\overline{-}$ & - & $\begin{array}{l}+ \\
+\end{array}$ & + & $\begin{array}{l}+ \\
+\end{array}$ & $\begin{array}{l}+ \\
+\end{array}$ \\
\hline \multirow{3}{*}{$\begin{array}{l}\text { OLe } \\
(a+b-)\end{array}$} & $\begin{array}{l}\text { 抗O(H) } \\
\text { ウナギ向清 }\end{array}$ & $\begin{array}{l}\text { 前 } \\
\text { 後 }\end{array}$ & - & - & - & - & + & $\begin{array}{l}+ \\
+\end{array}$ \\
\hline & $\begin{array}{l}\text { 抗L } \mathbf{e}^{\mathrm{a}} \\
\text { ウサザ血清 }\end{array}$ & 前 & $\bar{t}$ & $\bar{t}$ & $\bar{t}$ & $\begin{array}{l}+ \\
+\end{array}$ & $\begin{array}{l}+ \\
+\end{array}$ & $\begin{array}{l}+ \\
+\end{array}$ \\
\hline & 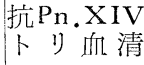 & 前 & - & - & - & - & - & $\begin{array}{l}+ \\
\pm\end{array}$ \\
\hline A & $\begin{array}{l}\text { 抗 } \mathrm{A} \\
\mathrm{t} \text { 血清 }\end{array}$ & $\begin{array}{l}\text { 前 } \\
\text { 後 }\end{array}$ & - & - & - & $\overline{+}$ & $\overline{+}$ & $\begin{array}{l}+ \\
+\end{array}$ \\
\hline B & $\begin{array}{l}\text { 抗 B } \\
\text { 比 保清 }\end{array}$ & 前 & - & - & 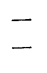 & - & - & $\begin{array}{l}+ \\
+\end{array}$ \\
\hline
\end{tabular}

ウサギ血清中の凝集素に対する吸収力や， $\mathrm{B}$ 型 血球の抗B凝集素に対する吸収力には作用前後 で変化を垫めない，従ってこの菌の産生する酥 素は水溶性の $\mathrm{Le}^{\mathrm{a}}$ 物質とA型物質のLe ${ }^{\mathrm{a}}$ 活性と A活性とを破壊するだけでなく，血球のそれを も分解するが， $\mathrm{Le}^{\mathrm{b}}, \mathrm{O}(\mathrm{H})$ ，拉よび B 型物質 を分解しない。

\section{3. 酵素の性状}

本菌は普通寒天平板上によく発育し, 菌の融 解液中に活性度の高い酵素を証明できるが，硫

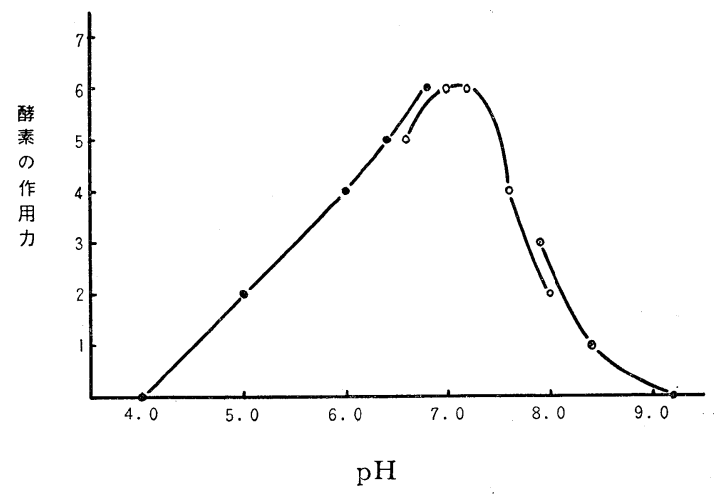

$\odot \longrightarrow 0$ citrate-phosphate buffer

0 - 0 phosphate buffer

boric acid-borax buffer

図醄素の作用力と $\mathrm{pH}$ との關係 
安塩析では30-60\%飽和で沈澱する分画に最も 強、酵素活性を認めることができる。硫安塩析 で得られた酵素標品を DEAE cellulose colu一 $\mathrm{mn}$ に吸着さ也, 燐酸緩衝液で段階的に溶出す ると, $\mathrm{pH} 6.8$ で0.01M 万至0.1M の濃度で溶出 される分画に $\mathrm{Le}^{\mathrm{a}}$ 特異性分解酵素が 認められ た.しかし $\mathrm{pH} 6.8$ 万至 $\mathrm{pH} 8.0$ の燐酸緩衝液で 溶出される分画中には少量のためか $\mathrm{A}$ 分解醰素 の活性を認めることはできなかったた。つぎに， この菌の出す酵素を citrate-phosphate buffer $(\mathrm{pH} 4.0-5.8)$, phosphate buffer $(\mathrm{pH}$ $6.6-8.0)$, boric acid-borax buffer $(\mathrm{pH}$ 7.6-9.2) をもちい，いろいろな $\mathrm{pH}$ のをとで $\mathrm{Le}^{\mathrm{a}}$ およびA型物質に作用させ，型作用の減弱 度から酵素の作用力をしらべてみると図示のご とく, $\mathrm{Le}^{\mathrm{a}}$ 分解作用, $\mathrm{A}$ 分解作用の至適 $\mathrm{pH}$ いずれも6.8-7.2で，4.0以下抢よび9.2以上で

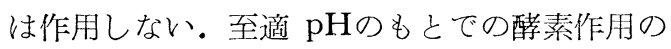
至適温度は30- $37^{\circ} \mathrm{C}$ であり， $20^{\circ} \mathrm{C}$ でもかなり 作用する。また酵素液は $60^{\circ} \mathrm{C} ， 5$ 分間の加熱で 活性が省しく弱まり，70 $\mathrm{C} ， 5$ 分間の加熱で全 くその作用を消失する。

\section{4. 酵素作用を阻止する金属塩および糖類}

本菌の出す $\mathrm{Le}^{\mathrm{a}}$ およびA分解酵素の作用は, 金属塩 (終濃度 $10^{-3} \mathrm{M}$ ) ではCuSO, $\mathrm{HgCl}_{2}$ お ょび $\mathrm{Sr}\left(\mathrm{NO}_{3}\right)_{2}$ で同程度に阻止される。糖類 （終濃度M/18）では表 4 に示すようにLe $\mathrm{Le}^{\mathrm{a}}$ 分 解醉素の作用は L-fucose, D-galactose, lactose $(O-\beta-\mathrm{D}$-galactopyranosyl- $(1 \rightarrow 4)-\mathrm{D}-$ glucose)で強く阻止され， $\beta$-ethyl- $N$-acetylD-glucosaminide, D-glucosamine で弱く, melibiose $(O-\alpha-\mathrm{D}$-galactopyranosyl- $(1 \rightarrow 6)$ -D-glucose), raffinose ( $O-\alpha-\mathrm{D}$-galactopyranosyl-( $1 \rightarrow 6$ )-O- $\alpha$-D-glucopyranosyl$(1 \rightarrow 2)$ - $\beta$-D-fructofranoside), $\quad N$-acetylD-glucosamine, $\alpha$-ethyl- $N$-acetyl-D-glucosaminide, D-galactosamine, L-arabinose でも僅かに阻止される. A分解酵素の作用は $N$-acetyl-D-galactosamineで強く, D-galactosamine でも弱く阻止される。このように
表 4 酵素作用を阻止する糖類

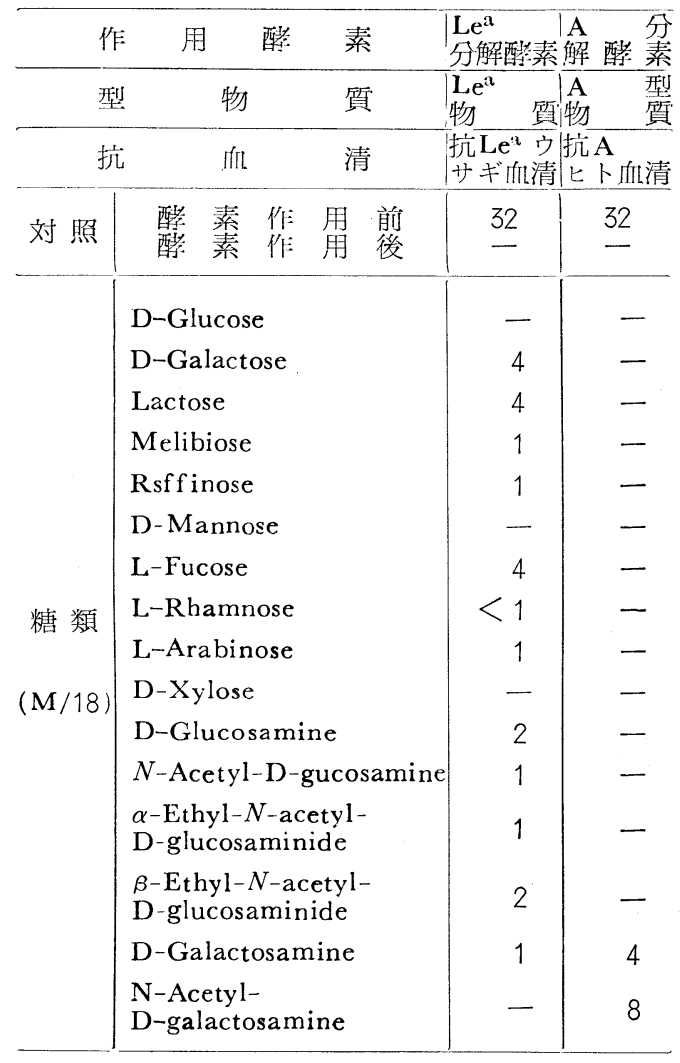

数字は凝集阻止作用を示す型物質の最終稀釈倍数

$\mathrm{Le}^{\mathrm{a}}$ 分解 酵素の作用が, L-fucose, D-galactose のほか $\beta$-D-galactosyl 基を含む lactose で強 く阻止され， $N$-acetyl-D-glucosamine を含む 糖でも阻止されることは, Watkins and Morg-

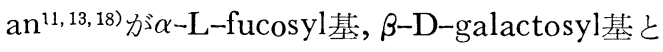
$\beta$-D- $N$-acetylglucosamine を合むlacto- $N$ fucopentaose II や lacto- $N$-difucohexaose II で抗Le ${ }^{a}$ 血清の反応が阻止されることから， $\mathrm{Le}^{\mathrm{a}}$ 特異性の決定群として $\alpha$ - $\mathrm{L}-\mathrm{f}$ ucose $か ゙ 1 \rightarrow 4$ , で $\beta$-D-galactose が1 $\rightarrow 3$ で $\beta-\mathrm{D}-N$-acetylglucosamine と結合している糖類を想定してい ることと一致した絬果を示している.

総括

1) Lewis 式血泎型の型物質のうち, 水溶性 の $\mathrm{Le}^{\mathrm{a}}$ 物質や $\operatorname{Le}(\mathrm{a}+\mathrm{b}-)$ 型血球に作用して $\mathrm{Le}^{\mathrm{a}}$ 活性を破壊する醳素を産生するBas，cer- 
eusに類似した菌を土瓖中より見出した。本菌 の出す酵素中にはA分解酵素も含まれている が, $\mathrm{O}(\mathrm{H}), \mathrm{Le}^{\mathrm{b}}$ および B分解酵素は含まれ ていない. $\mathrm{Le}^{\mathrm{a}}$ 物質や Le $(\mathrm{a}+\mathrm{b}$-) 型血球に この菌の出す酵素を作用させると, 抗肺炎双球 菌XIV型トリ血清に対する反応性が増強す る.

2）本菌のLe ${ }^{\mathrm{a}}$ およびA分解酵素は菌の融解 液の硫安30-60\%飽和で沈澱する部分に認めら れるが, DEAE cellulose column chromatographyにより，Le $\mathrm{Le}^{\mathrm{a}}$ 特異性分解酵素を分離 することができる。これらの酵素はいずれも至 適 $\mathrm{pH}$ は6.8-7.2で, 至適温度は $30-37^{\circ} \mathrm{C}$ であ り, $70^{\circ} \mathrm{C}, 5$ 分間の加熱で不活性化される.

3)これらの酵素の作用は金属塩では $\mathrm{CuSO}_{4}, \mathrm{HgCl}_{2}, \mathrm{Sr}\left(\mathrm{NO}_{3}\right)_{2}$ で阻止され, 糖類で はLe $\mathrm{a}^{\mathrm{a}}$ 分解酵素の作用は L-fucose, D-galactose および $\beta$-D-galactosyl 基を含む lactose で最も強く, $\beta$-ethyl- $N$-acethyl-D-glucosaminide, D-glucosamine でも弱く阻止され る. 酵素作用を阻止する糖の種類からみて, $\mathrm{Le}^{\mathrm{a}}$ 特異性の決定群には L-fucose と $\beta$-結合 の galactose とが最も重要な役割をはたし，さ らに $\beta-\mathrm{D}-N$-acetylglucosamine も関与して いることが考えられる. またこの菌の出す $\mathrm{A}$ 分 解酵素の作用は $N$-acetyl-D-galactoṡamine で 強く, D-galactosamineでも弱く阻止される。

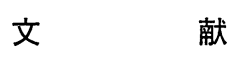

1) Grubb, R. and Morgan, W. T. J. : The "Lewis" blood group characters of erythrocytes and body-fluids. Brit. J. Exp. Path., 30(2) : 198-208, 1949.

2) Watkins, W. M. : The serological inactivation of the human blood-group substances by an cnzyme preparation ubtained from Trichomonas fcetus. Biochem. J., 54(4): xxxiii, 1953.

3) Watkins, W. M. : Enzymes of Trichomonas fcetus. The action of cell-free extracts on blood-group substances and low-molecular-weight glycosides. Biochem. J., 71(2) : 261-274,
1959.

4) Pusztai, A. and Morgan, W. T. J. : A bloodgroup-specific sialomucopolysaccharide possessing virus-receptor actvity. Biochem. J., 74(3) : $31 \mathrm{p}-32 \mathrm{p}, 1960$.

5) Pusztai, A. and Morgan, W. T. J. : Studies in immunochemistry. 18. The isolation and properties of a sialomucopolysaccharide possessing blood-group Le ${ }^{\mathrm{a}}$ specificity and virus-receptor activity. Biochem. J., 78(1) : 135-146, 1961.

6) Pusztai, A. and Morgan, W. T. J. : Degradation of blood group-specific mucopolysaccharides by ficin and papain. Nature, 182(4636) : 648-650, 1958.

7) Pusztai, A. and Morgan, W. T. J.: Studies in immunochemistry. 20. The action of papain and ficin on blood-group-specific substances. Biochem. J., 81(3) : 639-647, 1961.

8) Morgan. W. T. J. and Pusztai, A. : Studies in immunochemistry. 21. The products of the degradation of blood-group-specif ic substances by ficin and papain. Biochem. J., 81(3): 648-658, 1961.

9) Watkins, W. M. and Morgan, W. T. J. : Specific inhibition studies relating to the Lewis blood-group system. Nature, 180(4594) : 1038-1040, 1957.

10) Kuhn, R., Baer, H. H. und Gauhe, A. : 2- $\alpha$-L-Fucopyranosyl-D-galactose und 2- - L-Fucopyranosyl-D-talose. Zur Einwirkung von Alkali auf Oligosaccharide.

Liebigs Ann. Chem., 6i1: 242-249, 1958.

11) Kuhn, R. und Gauhe, A. : Über die Lactodifuco-tetraose der Frauenmilch. Fin Beitrag zur Strukturspezifiät der Blutgruppensubstanz Le ${ }^{b}$. Liebigs Ann. Chem., 611:249-253, 1958.

12) Kuhı, R. und Gauhe, $\Lambda$. : Über cin sristallisiertes, Le $\mathrm{L}^{\mathrm{a}}$-aktives Hexasaccharid aus Frauenmilch. Chem. Ber., 93: 647-651, 1960.

13) Watkins, W. M. and Morgan, W. T. J. : Further observations on the inhibition of blood-group specific serological reactions by 
simple sugars. Vox Sang., 7(2): 129-150, 1962.

14) Kuhn, R. und Baer, H. H. : Die Konstitution der Lacto-N-tetraose. Ghem. Ber., 89,2) : 504-511, 1956.

15) Kuhn, R., Baer, H. H. und Gauhe, A. : Kristallisation und Konstitutionsermittlung der Lacto-N-f ucopentaose I . Chem. Ber., 89(11) : 2514-2523, 1956.

16) Kuhn, R., Baer, H. H. und Gauhe, A. : Die Konstitution der Lacto-N-fucopentaose II. Chem. Ber., $91: 364-374,1958$.

17) Kuhn, R., Baer, H. H. und Gauhe, A. : Fucosido-lactose, das Trisaccharid der
Frauenmilch. Chem. Ber., 88(8): 1135-1146. 1955.

18) Watkins, W. M. : Changes in the specificity of blood-group mucopolysaccharides induced by enzymes from Trichomonas foetus. Immunol., 5(2) : 245-266, 1962.

19) Sneath, J. S. and Sneath, P. H. A. : Transformation of the Lewis groups of human red cells. Nature, 176 (4473) : 172, 1955.

20）古川 研, 藤沢敬一, 茂木 治 : 型物質々肺炎双 球菌 XIV 型との共通抗原物質を分解する酵素の 血清学的作用. 北関東医学, 12(4): 266-276, 1962.

\section{STUDIES ON Le ${ }^{a}$-DECOMPOSING ENZYME}

\section{SEROLOGICAL AGTION OF THE ENZYME}

Ken Furukawa, Keiichi Fujisawa and Osamu Motegi :

Department of Legal Medicine, School of Medicine, Gunma

University, Maebashi (Director : Prof. Shoei Iseki)

1. A strain of Bacillus ceeus was isolated from the soil which produced an enzyme acting on water-soluble Le $\mathrm{Le}^{\mathrm{a}}$ substance and group $\mathrm{OLe}(\mathrm{a}+\mathrm{b}-)$ red cells. The enzyme preparation also contains A-decomposing enzyme, but not $\mathrm{O}(\mathrm{H})-$, Le $\mathrm{e}^{\mathrm{h}}$-and $\mathrm{B}$-decomposing enzymes. Decomposition of $\mathrm{Le}^{\mathrm{a}}$ activity of $\mathrm{Le}^{\mathrm{a}}$ substanse and $\mathrm{Le}(\mathrm{a}+\mathrm{b}-)$ red cells with this enzyme resulted in the enhancement of the cross-reactivity of $L^{a}$ substance and Le $(a+b-)$ red cells with anti-pneumococci Type XIV chicken serum.

2 . These enzymes were found in a fraction which precipitated at $30-60 \%$ ammonium sulfate saturation of bacterial autolysate. By means of DEAE cellulose column chromatography, the Le decomposing enzyme could be separated from the A-decomposing enzyme. The optimal pH of these enzyme action ranged 6.8-7.2, the optimal temperature $30-37^{\circ} \mathrm{A}$. and the enzymes were inactivated by heating at $70^{\circ} \mathrm{C}$ for 5 minutes.

3. The action of these enzymes were inhibited by such metal salts as copper sulfate, mercuric chloride and strontium nitrate. The enzyme action to decompose Le ${ }^{a}$ substance was inhibited strongly by $\mathrm{L}$-fucose, D-galactose and lactose, and slightly by $\beta$-ethyl- $N$-acetyl-D-glucosaminide and $D$-glucosamine. The results of the inhibition of enzyme action by sugars indicate that the structure of $\mathrm{L}$-fucose and $\beta$-linked $\mathrm{D}$-galactose combined with $\beta$-D- $N$-acetylglucosamine is important as antigenic determinant of $\mathrm{Le}^{\mathrm{a}}$ specificity. The action of A-decomposing enzyme was inhibited strongly by $N$-acetyl-D-galactosamine and slightly by D-galactosamine. 